\title{
INTERCULTURAL COMMUNICATION \\ AS A SOCIAL PHENOMENON
}

\section{МІЖКУЛЬТУРНА КОМУНІКАЦІЯ \\ ЯК СУСПІЛЬНИЙ ФЕНОМЕН}

\section{Valentina Zhuk ${ }^{1}$}

DOI: https://doi.org/10.30525/978-9934-26-001-8-1-11

Abstract. The work is devoted to the study of forms, models and principles of the organization of intercultural communication, as well as the peculiarities of their functioning in dialogical statements. The relevance of the topic is due to the need to develop problems of typologization of the principles of intercultural communication (IC) and the conditions for their speech implementation interest in which is dictated by changes in society, the expansion of interaction between cultures and peoples. The problems of cultural identity, cultural differences and mutual understanding are especially relevant. The subject of the research is intercultural communication in Ukrainian and English linguistic cultures. The object of the research is the typology of models, forms and principles of the organization of intercultural communication, their speech realization in the analyzed linguocultures.

The aim of the study is to analyze scientific data on the problems of typologizing models, forms and principles of intercultural communication, to generalize its semantics and pragmatics in each of the studied linguocultures, to determine the typology of models, forms and principles of organizing intercultural communication.

The definition of intercultural communication is obvious from the term itself: it is the communication of people representing different cultures. We adhere to the following definition: «Intercultural communication is an adequate understanding of two participants in a communicative act belonging to different national cultures.»

Intercultural communication as a social phenomenon was brought to life by the practical needs of the post-war world, which were supported

\footnotetext{
${ }^{1}$ Senior Teacher of the Department of English Grammar, Odesa I.I. Mechnikov National University, Ukraine
}

(C) Valentina Zhuk 
by changes in public consciousness, in recognition of absolute value of the diversity of world cultures in the rejection of the colonial cultural policy, in the awareness of the fragility of existence and the threat of destruction of most traditional cultures and languages. Currently, there are various approaches to describing the intercultural and intracultural interaction of people in society, but the study of linguistic and semiotic models of communication is not given due attention either in domestic or foreign linguistic knowledge.

The Western communication models described in the work do not meet contemporary requirements. Acquaintance with the works of Western scientists allows us to assert: used methods and approaches do not cover and do not describe all aspects of intercultural communication. IC can be explored either at the group level or at the individual level. Most of the research carried out at the group level was of an anthropological and sociological nature. They were based on two methodological approaches: 1) «understanding of cultures as cognitive systems», which is described by V. Gudenaf; 2) understanding of culture as a «symbolic system» the opposite approach of K. Geertz. The state of contemporary society, in which one of the main problems is the problem of intercultural interaction, has led to a heightened interest in the research of cultural anthropologists who have developed a new understanding of the foundations of the existence of culture. Historically, contemporary communicative linguistics, continuing the traditions of F. Schleiermacher and his «general» hermeneutics, which studied the process of understanding and its regularities, focused on the conditions for only successful communication. At the heart of any process of understanding is precisely the principle of interaction between parts and the whole, which is a prerequisite for the application of the systemic method in each specific area of research. In this way, an understanding of both the behavior of people and the products of their cultural and historical activities occurs.

\section{1. Вступ}

Стаття присвячується дослідженню форм, моделей та принципів організації міжкультурної комунікації, а також особливостям їх функціонування в діалогічних висловлюваннях. Актуальність теми зумовлена необхідністю розробки проблем типологізації принципів міжкультурного спілкування та умов їх мовних реалізацій, інтерес до яких 
продиктований змінами в суспільстві, розширенням взаємодії культур і народів. Особливо актуальними $є$ проблеми культурної самобутності, культурних відмінностей і взаєморозуміння. У науці проблеми організації міжкультурної комунікації досліджуються як вченими-філологами (М.М. Бахтін, П. Грайс, Л.М. Міхайлов, Г.П. Немец), так і філософами, фізиками, соціологами, антропологами, культурологами (I. Кант, Л. Вітгенштейн, Ф. Шлейермахер, Х. Гадамер, Е. Сепір, Б. Уорф, Р. Якобсон, С.Г. Тер-Мінасова, В.П. Кузовлев, В.Г. Костомаров). Предметом дослідження є міжкультурна комунікація (МК) в українській та англійській лінгвокультурах. Об'єкт дослідження - типологія моделей, форм та принципів організації міжкультурної комунікації, їх мовні реалізації в аналізованих лінгвокультурах.

Визначення міжкультурної комунікації очевидно з самого терміна: це спілкування людей, які представляють різні культури. Ми дотримуємося наступного визначення Е.М. Верещагіна та В.Г. Костомарова: «Міжкультурною комунікацією називається адекватне взаєморозуміння двох учасників комунікативного акту, які належать до різних національних культур» [2, с. 83]. Міжкультурна комунікація як суспільний феномен з'явилася завдяки практичним потребам повоєнного світу, які були підтримані змінами в суспільній свідомості, у визнанні абсолютної цінності різноманітності світових культур, у відмові від колонізаторської культурної політики, в усвідомленні крихкості існування та загрози знищення величезної більшості традиційних культур та мов.

Необхідність міжкультурних комунікацій у сучасному суспільстві, їх специфіка та функції були розглянуті дослідниками (Н.К. Васютіна, Т.В. Емельяненко, Н.К. Іконнікова, Л.А. Самофалова, С.Г. Тер-Минасова, Р. Льюіс, Т. Тен, Г. Хофстеде та ін. Особливий інтерес представляють дослідження, направлені на вивчення включення особистості в систему культури (або інкультурацію) та функцій контролю за поведінкою особистості, які здійснює культура. До подібних досліджень відносяться роботи представників американської культурної антропології (Ф. Боаса, Ф. Бок, А. Кардінер, Е. Сепір та інші). Великий основний внесок в теорію впливу мови на образ мислення та поведінки людини внесли Е. Сепір та його послідовник Б. Уорф. Відомо, що контакти та відносини між культурами виникають в результаті різних причин. В сучасних умовах бурхливе розвинення міжкультурної 
комунікації відбувається в самих різних сферах життя: туризм, спорт, військове співробітництво, особистих контактах і т.д. Соціальні, політичні та економічні зміни в світовому масштабі привели до небувалої міграції народів, їх переселення, змішанню та зіткненню. В результаті цих процесів все більше людей переступають культурні бар'єри, які розділяли їх раніше. Формуються нові явища культури, межі між своїм та чужим стираються. Виникаючі при цьому зміни охоплюють практично всі форми життя та отримують в різних культурах неоднозначну оцінку. Ці оцінки найчастіше відзначаються особливостями взаємодіючих культур. Датою народження міжкультурної комунікації як академічної дисципліни слід вважати 1954 рік, коли вийшла в світ книга Е. Хол та Д. Трагера «Culture as Communication» («Культура як комунікація»), в якій автори вперше запропонували для широкого вживання термін «міжкультурна комунікація», який відображав, на їхню думку, особливу частину людських відносин. Пізніше основні положення та ідеї міжкультурної комунікації були більш докладно розвинені в дослідженні Е. Хол «The Silent Language» («Німа мова»), де автор показав тісний зв'язок між культурою та комунікацією.

У вітчизняній науці та системі освіти ініціаторами вивчення міжкультурної комунікації стали викладачі іноземних мов, які першими усвідомили, що для ефективного спілкування з представниками інших культур недостатньо одного володіння іноземною мовою. Навіть глибокі пізнання в галузі іноземних мов не виключають випадків нерозуміння, «комунікаційного провалу». У роботі Е. Хол під міжкультурною комунікацією розуміється ідеальна мета, до якої повинна прагнути людина в своєму прагненні якнайкраще й ефективніше адаптуватися до навколишнього «ворожого» світу. 3 тих пір дослідники досить далеко просунулися в розробці цього теоретичного феномена, який пояснюють відмінностями в когнітивній базі мовців та в колективному комунікативному просторі. Для міжкультурної комунікації необхідне усвідомлення учасниками комунікації культурних відмінностей один від одного. За своєю сутністю міжкультурна комунікація - це завжди міжособиста комунікація в спеціальному контексті, коли один учасник виявляє культурну відмінність від іншої.

Не викликає сумнівів, що спілкування можна віднести до міжкультурного, якщо воно відбувається між представниками різних 
національно-культурних спільнот, а відмінності між культурами призводять до труднощів у спілкуванні. Ці труднощі пов'язані з відмінностями в очікуваннях та упередженнях, властивих кожній людині як представнику певного соціуму, які відрізняються в різних культурах. У представників різних культур по-різному відбувається породження та дешифрування висловлювання, і це стає значущим тільки в акті комунікації та призводить до непорозумінь та напруженості, труднощів та неможливості спілкування. Міжкультурна комунікація грунтується на процесі символічної взаємодії між індивідуумами та групами, культурні відмінності яких можна розпізнати. Сприйняття та ставлення до них впливають на вид, форму і результат контакту, так як кожен учасник комунікативного акту володіє своєю власною системою правил та стереотипів, які функціонують таким чином, щоб відправлена інформація могла бути адекватно сприйнята, дешифрована. Ознаки міжкультурних відмінностей можуть бути інтерпретовані як відмінності вербальних та невербальних кодів в специфічному контексті комунікації. На процес інтерпретації, крім культурних відмінностей, впливають і інші пропозиції, які залежать від віку, статі, освіти та соціального статусу мовця. Тому ступінь міжкультурного кожного конкретного акту комунікації залежить від толерантності, особистого досвіду його учасників.

\section{2. Типи культури}

Сучасна теорія міжкультурної комунікації спирається не тільки на досягнення загальної теорії комунікації, теорії комунікативних актів і лінгвістичної прагматики, а на базові поняття та уявлення даної наукової дисципліни, які склалися в результаті довготривалих лінгвістичних та філософських досліджень, що здійснюються в рамках вивчення зв'язків мови та культури. Сучасна лінгвістика, звертаючись до проблеми «мова і культура», прагне піти від одностороннього детермінізму та не вирішувати, що є первинним, а що вдруге: мова чи культура. Зв'язок мови і культури взаємний, тому набагато надійніше шукати ті чи інші кореляції між структурами мови та культури на широкому географічному та історичному просторі. У руслі цих пошуків В.М. Гаспаров запропонував поняття лінгвокультурний тип, яке може бути виявлено на перетині фактів соціальної культури, побу- 
тової поведінки, мистецтва та особливостей мови [3]. Виділені два типи культури: західноєвропейський стандарт (ЗСС) та східноєвропейський стандарт (СЭС). Мови ЗСС визначаються В.М. Гаспаровим як «реляційні». Для них характерна чітка межа між граматикою та лексикою та більш абстрактне представлення інформації в висловлюванні. Мови ВEC - це мови «дескриптивні» (описові). Тут граматика ближче до лексики; велика кількість проміжних лексико-граматичних категорій сприяє більш конкретної передачі інформації. Особливості BEC узгоджуються з його проміжним положенням між східним (азіатським) та західним лінгвокультурними типами. Для культур західного типу характерні легкість оволодіння листом, доступність сприйняття будь-яких текстів та створення нових текстів. Це пов'язано з тим, що лад західних мов добре пристосований до абстрактного типу передачі повідомлення, для якого несуттєвий контакт мовця з адресатом. Граматика тут як би моделює ситуацію написання тексту. Мова будується таким чином, щоб ії можна було зрозуміти без опори на конкретну, безпосередньо сприйняту ситуацію спілкування, вона не орієнтована на конкретного адресата. Абстрактний характер передачі повідомлення виражається в тому, що в таких мовах ослаблені граматичні категоpiї соціальної орієнтації (наприклад, категорія ввічливості), категорії дієслівного виду та способу дії. Зате граматично розвинені категорії, які вказують на зовнішні (тимчасові, просторові) координати події, яка повідомляється (категорія часу та особи).

Східно азійському типу культури, для якого характерно обмежене поширення писемності, відповідає лад мови, в якому кожне речення містить граматичну характеристику ситуації усного спілкування, де важливі всі складові комунікативного акту: характер контакту мовців, їх соціальний статус та взаємини, конкретні деталі перебігу дії, модальний план та актуальне членування речення. Залежність між певними рисами структури мови та характером писемної культури В.М. Гаспаров бачить у великій кількості звукових чергувань у морфемах, що полегшує вичленення фонем та сприяє ранньому створенню літерного письма, яке в силу простоти (в порівнянні із ієрогліфічним письмом) призводить до широкого поширення письменної культури. Гіпотези В.М. Гаспарова про вплив мови на культуру та мислення поки не переростають в доказові теорії. Феномен культури складний. 
До сих пір не ясна його структура, значимість окремих рівнів та підсистем культури; не створена типологія культур, не зрозумілі закони їх розвитку. Однак при цьому не можна не відзначити найцікавіші думки із семіотної типології різних культур, які висловлені Ю.М. Лотманом, який визначив культуру як сукупність неспадкової інформації, як загальної пам'яті людства або будь-якого людського колективу. Вчений вважав, що ми маємо право розглядати культуру як визначену суму текстів, вербальних та невербальних, як певні повідомлення (тексти) і як реалізацію кодів, за допомогою яких ці повідомлення дешифруються (сприймаються, розуміються, інтерпретуються). Розгляд культури 3 цієї точки зору переконує в можливості опису типів культури як особливих мов та робить можливим застосування до них методів, використованих при вивченні семіотичних систем. При цьому важно враховувати, що реальні тексти (під текстом в даному випадку ми розуміємо не тільки вербальні одиниці, а й схеми поведінки - ритуали, звичаї і т.д.) різних культур вимагають для свого дешифрування не одного будь-якого коду, а складної системи кодів, яка іноді ієрархічно організована, а іноді виникає в результаті механічного з'єднання більш простих систем. Так, наприклад, який-небудь обряд включає в себе безліч семіотичних систем, які організовують поведінку людини: мовна поведінка (мова), дії людини, одяг, вибір місця і т.д.

\section{3. Семіотичні типи культури}

Розглядаючи семіотичні типи організації культури, Ю.М. Лотман виділяє наступні домінантні варіанти відносин між знаками: код культури являє собою лише семантичну організацію; код культури являє собою лише синтаксичну організацію; код культури являє собою установку на заперечення обох видів організації, тобто на заперечення знаковості; код культури являе собою синтез обох видів організації. Ю.М. Лотман зазначає, що ідеальна схема культури завжди організовується за аналогією з деякими відомими в даному колективі типами комунікації. В основі охарактеризованих вище типів коду культури лежить антиномія слова і тексту.

Символічний, або семантичний, тип культури побудований на символізації як навколишньої для людини дійсності та іï частин. Його зазвичай називають середньовічним, оскільки в найбільш 
чистому вигляді він представлений в середньовічній культурі народів Європи. Синтаксичний тип культури знайшов своє вираження в практицизмі нового часу. Він призводить до високої оцінки корисних знань, з одного боку, та іронічно-зневажливим ставленням до чисто теоретичного мислення, з другої. Здоровий глузд людини ставав мірою реальності. Те, що він не визнавав істотним, виключалося 3 сфери культури. Однак прагнення до десеміотізаціі (позбавлення символічної значущості) цінностей культури не означало відмови від всіх видів знаковості. Семантична структура знаку замінювалося синтаксичною. Значення тієї чи іншої людини або явища визначалося не співвідношенням його з сутностями іншого ряду, а включенням в певний ряд.

В історично кризові моменти, коли соціальні інститути дискредитовані і сама ідея суспільства сприймається як синонім пригнічення, виникає система культури, організуючою основою якої є прагнення до десеміотізаціi. У європейській культурі нового часу, найбільш повним вираженням цього культурного коду явилась просвіта. На відміну від семантико-символічної структури Середньовіччя, вона виходила з уявлення, що найбільшою цінністю володіють ті реальні речі, які можуть бути інтерпретовані у якості знаків: не гроші, мундири, чини або репутації, а хліб, вода, життя, любов. Таким чином, обидва змістотворчих принципів попередніх культур входили в цю систему в негативному вигляді, як мінус-компоненти. Ідеї Просвітництва, поклавши в основу всієї організації культури опозицію «природне - неприродне», різко негативно ставляться до самого принципу знаковості.

Уявлення про світ як про деяку послідовність реальних фактів, які $€$ вираженням глибинного руху духу, надавало всім подіям подвійну свідомість: семантичну - відношення фізичних проявів життя до їх прихованого змісту - та синтаксичну - їх відношення до історичного цілого. Це прагнення до осмисленості і було основною рисою європейської культури кінця XVIII - початку XIX століття, яка представляла собою семантико-синтаксичний тип культури. Світ розпадався на систему: ідеальну сутність та матеріальне ії вираження в випадковому для неї втіленню. Така в цілому семантична типологія культури, яку розробив Ю.М. Лотман. В іiї основі - системне творення знаків культури, які складають ії коди. 
Будучи одним з найважливіших досягнень соціальної діяльності людини, мова є і доданком культури, і iї знаряддям: мова виступає як явлення культури та природи. Однак в самій матерії мови, в ряді істотних характеристик мовної структури позначилася біологічна природа людини. Сучасним знанням відкривається разюче глибоке взаємопроникнення природи та культури, і мова є одним з яскравих проявів зазначеного. У молекулярній біології та семіотиці вченим вдалося відмітить унікальну структурну схожість генетичного коду та мови. Вони розглядаються як інформаційні системи, які слугують для породження текстів шляхом комбінаторики деяких вихідних елементів: в механізмах генетики - чотирьох хімічних радикалів при розгортанні «хімічного тексту» спадковості; в механізмах мови - набір фонем при породженні мови. Р. Якобсон висловив припущення, що «схожість 3 генетичним кодом з'явилося в результаті того, що в процесі філогенезу людина несвідомо конструювала мову за зразком генетичного коду. Це копіювання генетичного коду в мові можливо завдяки тому, що організм несвідомо володіє інформацією про свою будову, в тому числі і про будову свого генетичного коду» [12, с. 234].

Подібно до того, як в культурі кожного народу є загальнолюдське та етнонаціональне, в семантиці кожної мови є відображення як загального, універсального компонента культур, так і своєрідності культури конкретного народу. Універсальний семантичний компонент обумовлений єдністю бачення світу людьми різних культур. Ця принципова єдність людської психіки проявляється на різних рівнях семантичної організацій мов - від широких та стійких тенденцій до точкових універсальних явищ. Так, в будь-яких культурах мовці потребують розрізнення суб'єкта дії та його об’єкта, предмета і ознаки, тих чи інших часових та просторових відносин. Міжкультурна схожість самих процесів мовного спілкування проявляється в тому, що всі мови розрізняють мовця, слухача та неучасника спілкування (в цьому призначенні категорія особи - 1-а, 2-а та 3-я особа); всі мови розрізняють питання і затвердження; всюди в повідомлення вплітаються модальні або емоційні оцінки мовцями того, про що йде мова. Спільність людської психології яскраво позначається в асиметрії позитивних та негативних оцінок, зафіксованих в мові. Якщо розглядати синонімічні ряди оцінних слів, то слова 3 негативною оцінкою будуть домінувати над 
словами $з$ позитивною оцінкою. Міжкультурна спільність людського бачення світу зумовила антропоморфну універсальність тієї наївної картини світу, яка відображена в природних мовах. В усіх мовах позначення абстрактного та ідеального в своїх витоках сходить до позначень конкретного та матеріального. У самих різних культурах людина називає нове за допомогою раніше створених імен, звужуючи або розширюючи їх семантику за допомогою метафор або метонімії.

\section{4. Культура та мова}

Вплив культури на мову яскраво і цілісно проявляється в тому, в яких формах існування представлена та чи інша мова. $€$ мови, де майже відсутні діалекти i, навпаки, де відмінності між діалектами дуже значні. $\mathcal{C}$ мови, в яких ще не склалися над діалектні форми спілкування (койне або літературна мова), і мови з сильною багатовіковою книжково-письмовою традицією над діалектного характеру. У молодих літературних мовах стилістична диференціація може тільки починатися: в цьому випадку, наприклад, в стилістиці переважає протиставлення нейтральних та розмовних мовних засобів; публіцистика може бути близькою то до розмовної мови, то до канцелярсько-ділової; наукові, науково-популярні та навчальні тексти ще пишуться в одному стилістичному ключі. Навпаки, в мовах з тривалою і багатою письмовою традицією стилістична диференціація мовних та мовлєнневих засобів вельми глибока і багатовимірна. Взаємини між літературною мовою та нелітературними формами існування мови, глибина і характер стилістичної диференціації мовних засобів визначаються всім ходом культурної історії суспільства: історією його писемності, книговидання, школи, літератури, держави, його культурно-ідеологічними симпатіями та антипатіями в міжетнічних контактах.

Вплив культури народу на характер нормативно-стилістичного укладу носить більш опосередкований, але і більш глибокий характер, ніж вплив культури на словник. Якщо словник - це дзеркало культури, то нормативно-стилістична система - це іiі схематичне зображення. За лексикою представлений світ речей та уявлень, це порівняно зовнішнє зображення культурної мозаїки суспільства. Стилістика ж заснована на відносинах та зв'язках різного типу, вона регулює функціональне розподілення мовних засобів в текстах у відповідності зі сформова- 
ною в культурі ієрархією типів спілкування; це мовне відображення структурних особливостей культури.

Якщо вплив культури на мову цілком очевидний та різноманітний, то питання про зворотній вплив - мови на культуру - залишається відкритим. Погляд на світ, відображений в мові, розгортається в культурі народу. Однак в порівнянні з фольклором, мова виступає як ще більш давній, більш глибокий й органічний для етносу зміст. Тому так важко визначити роль мови в історії культури. Віра в визначальний вплив мови на духовний розвиток народу лежала в основі філософії мови німецького вченого В. Гумбольдта. У праці «Про відмінність будови людських мов та іiї вплив на духовний розвиток людства» він писав: «У кожній мові закладений самобутній світогляд. Як окремий звук постає між предметом і людиною, так і вся мова в цілому виступає між людиною і природою, яка взаємодіє на нього зсередини і ззовні. I кожна мова робить навколо народу, якому вона належить, коло, звідки людині дано вийти лише тому, що вона тут же вступає в коло іншої мови» [4, с. 108]. Вчений бачив в мові магічну духовну силу, яка піднімає людину, перетворює їі в homo sapiens. «Розуміння самобутнього життя народу і внутрішнього ладу окремої мови, так само як ступеня іiі відповідності вимогам мови взагалі, цілком залежить від уміння побачити своєрідність національного духу в його повноті. Адже лише він, яким його створила природа і сформували обставини, визначає собою національний характер, на цьому засноване все творче в історії нації, в іiі установах, іiі думки; в ньому відображені іï сила та гідність, яка дістається від неї в спадок індивідам. Разом з тим мова є орган внутрішнього буття, навіть саме це буття, наскільки воно крок за кроком домагається внутрішньої ясності та зовнішнього втілення. Вона [мова] усіма найтоншими нитками свого коріння зрослася з силою національного духу, і чим сильніше вплив духу на мову, тим більш закономірний і багатший розвиток останньої. У всьому своєму стрункому сплетінні вона є лише продукт мовної свідомості нації ...» [4, с. 110]. Концепція зв'язку мови і культури народу В. Гумбольдта до теперішнього часу вивчена не так глибоко, як хотілося б. Загальновідомі його твердження про те, що мова перебуває в нерозривному зв'язку з «духом» народу, але немає ні визначень, ні навіть припущень про зміст поняття «дух» в лексиконі вченого. «Мова $є$ як би зовнішній прояв духу народів: 
мова народу є його дух, i дух народу є його мова, і важко уявити собі що-небудь більш тотожне». На загальну думку, дане поняття включає в себе і спосіб пізнання світу, і когнітивну базу носіїв мови, і модель сприйняття світу. Так, в передмові до робіт В. Гумбольдта «Вибрані роботи з мовознавства» професор Г.В. Рамішвілі пише: «Вільгельм фон Гумбольдт увів поняття «дух народу» в порівняльне мовознавство як поняття необхідне, проте його важко осягнути в чистому вигляді: без мовного вираження «дух народу» - неясна величина, знання якої слід брати знову-таки з самої мови, мова ж тлумачиться не тільки як засіб для осягнення «духу народу», а й як фактор його творення» [8, с. 330]. А між тим вчений неодноразово наголошував, що дух народу - це діяльність: «буття духу може мислитися тільки в діяльності і в якості такої»; «Сила духу впливає на артикуляцію і змушує органи мови відтворювати звуки відповідно до форм своєї діяльності» [8, с. 331]. Оволодіння мовою, відмінної від рідної, відкриває людині нові нюанси сприйняття дійсності, «створює додаткові виміри реальності». Подолання мовних бар'єрів не завжди може бути здійснений тільки в результаті оволодіння та глибокого знання тієї чи іншої мови; дискурсивна практика (тобто спроба виходу за межі мови за допомогою самої мови), як правило, веде до встановлення взаєморозуміння між представниками різних культур. Незважаючи на жорстку залежність між типом мови та способом сприйняття світу, були виявлені деякі лінгвістичні універсалії, тобто мовні явища, загальні для всіх культур. Наприклад, при вживанні ряду слів (в основному ті, які висловлюють «радикальні», емоційно змістовні або поодинокі концепти, такі як «любов», «Бог», «батьки» і т.д.) виникають однакові емоційні асоціації у представників різних культур. Однак відмінності в сприйнятті світу виявляються у представників різних соціальних груп навіть в рамках суспільства, яке говорить однією мовою.

3 одного боку, різний зміст, вкладений в одні і ті ж поняття, веде до різної інтерпретації одних і тих же явищ. 3 іншого боку, один і той же сенс можна вкласти в різні поняття в залежності від соціальної групи.

Ідея про взаємозв'язок між мовою, комунікацією та світосприйняттям розвивається в працях одного з провідних теоретиків К. Хергена, який стверджував, що, тільки адекватно володіючи мовою, індивід здатний зрозуміти визначні норми і цінності, а отже, і полегшити шлях їх прийняття. 
У ситуації міжкультурного спілкування необхідно розуміти: те, що говорить представник іншої культури, є скороченою проекцією його внутрішнього світу. Навіть правильна та бездоганна мова завжди забарвлена в тони тієї картини світу, яка обумовлена жорсткою структурою рідної мови. Йдеться про дискурсивних особливості різних мов, про стилі висловлювання, обумовлених різними культурами. Так, наприклад, англійська мова лаконічна, точна, «буквальна» щодо граматики та лексики. Сама структура сучасної англійської мови характеризується краткістю, точністю, ввічливістю, передбачливістю. Німецька мова має строго дисципліновану та логічну структуру слів, які часто виражають складні поняття; монолог німців серйозний, сконцентрований на важливих проблемах i часто виражений книжними словами. Українська ж мова дуже гнучка як щодо лексики, так і в плані граматики. Це означає, що одна думка може бути виражена за допомогою необмеженої кількості лінгвістичних прийомів, одне речення (фраза, слово) може бути неоднозначно інтерпретовано. Монолог насичений, рухливий.

\section{5. Національний характер та мова}

Кожна національна мова не тільки відображає, а й формує національний характер. Інакше кажучи, якщо мова формує представника народу - носія мови, причому формує його як особистість, то він повинен грати таку ж конструктивну роль і в формуванні національного характеру. Перш ніж заглибитися в цю проблему, треба розглянути саме поняття - «національний характер». Наші перші уявлення про людину іншої культури, іншої національності формуються під впливом наших понять про національний характер. Якщо взяти літературних героїв національних літератур, то перш за все вражає їх контраст із стереотипними персонажами міжнародних анекдотів. Дійсно, легковажні французи із анекдотів на рівні своєї класичної літератури світового масштабу представлені драматичними героями О. Бальзака, В. Гюго, П. Меріме, Г. Мопассана, В. Золя, які рішають складні людські проблеми та не мають нічого спільного із легковажними героями. Чопорні та стримані до абсурду англійці з анекдотів створили літературу, повну іскристого гумору, іронії, сарказму: літературу Д. Свифта, Б. Шоу, О. Уайльда, Ч. Діккенса, У. Теккерея, В. Шекспіра у якого на 
п’ять трагедій припадає 22 комедії. У жодній культурі гумор не цінується так високо; анекдотичні російські алкоголіки внесли в скарбницю мирової літератури дорогоцінний внесок: твори А.С. Пушкіна, М.Ю. Лермонтова, Л.Н. Толстого, І.С. Тургенєва, А.П. Чехова, Ф.М. Достоєвського. Герої цих творів, з їх філософськими пошуками i тонкими душевними переживаннями, - це інтелігенти серед персонажів світової класичної літератури. Отже, художня література також, 3 деякими застереженнями, являс собою джерело інформації про національний характер. Нарешті, третє джерело, де можна і потрібно шукати «душу народу», - це усна народна творчість. У фольклору в цьому сенсі є велика перевага перед художньою літературою, оскільки фольклорні твори анонімні, за ними не стоїть індивідуальний автор, їх автор - народ, це колективна творчість. І останнім по порядку, але аж ніяк не за значенням (last - останній, but not least - але не найгірший), найнадійнішим та науково прийнятним свідченням існування національного характеру є національна мова. Мова і відображає, і формує характер свого носія, це самий об' єктивний показник народного характеру. Недарма I. Ільїн визначав мову як «фонетичне, ритмічне та морфологічне вираження народної душі» [5, с. 69].

Виходячи $з$ цієї думки, необхідно розглядати національний характер через призму мови. Тим самим виявити функції, які роз'єднують та об’єднують мову в процесі міжкультурної комунікації, іiі силу та можливості, показати ії сильні сторони. Розширення взаємодії культур і народів робить особливо актуальним питання про культурну самобутність та культурні відмінності. Культурне різноманіття сучасного людства збільшується та народи, які складають його, знаходять все більше ресурсів, щоб зберегти та розвивати свою цілісність та культурний вигляд. Ця тенденція до збереження культурної самобутності підтверджує загальну закономірність, яка полягає в тому, що людство, стаючи все більш взаємозалежним і єдиним, не втрачає свого культурного розмаїття. У контексті цих тенденцій суспільного розвитку стає надзвичайно важливим вміти визначати культурні особливості народів, щоб зрозуміти один одного і досягти взаємного визнання і взаєморозуміння з представниками різних лінгво-культур.

Подібно до того, як в культурі кожного народу є загальнолюдське та етнонаціональне, так і в семантиці кожної мови $є$ відображення як 
загального, універсального компонента культур, так і своєрідності культури конкретного народу. Універсальний семантичний компонент обумовлений єдністю бачення світу людьми різних культур.

Як уже зазначалося, головною відмітною особливістю процесу комунікації є обов'язкове взаєморозуміння партнерів. Без правильного сприйняття, оцінки та взаєморозуміння, весь процес комунікації втрачає сенс. Для ефективної та успішної комунікації із представниками інших культур необхідні певні знання, навички та здібності, які формують адекватне та вірне взаєморозуміння партнерів по комунікації. Дослідження вітчизняних та зарубіжних вчених проблеми міжкультурного взаєморозуміння дозволяють зробити висновок, що тут існує досить багато причин для нерозуміння і виникнення міжкультурних конфліктів. Ці причини прямо або побічно пов'язані із психологічним механізмом сприйняття і формуванням міжкультурної компетенції.

\section{6. Світ та людина}

Сприйняття світу людиною визначається багатьма факторами: вихованням, соціально-культурним середовищем, освітою, характером, світогляду зором, особистим досвідом і т.д. Всі ці фактори утворюють складну систему, спрямовану на сприйняття інформації, iï аналіз і формування відповідного типу поведінки. Вчені виділяють кілька видів сприйняття світу, серед яких головними є буденне та усвідомлене. В рамках цих видів сприйняття ще виділяється чуттєве сприйняття, коли мова йде про те, що людина сприймає, розуміє і пізнає. Процес комунікації починається із спостереження за партнером, його зовнішністю, голосом, особливостями поведінки і т.д. Сукупність цих спостережень становить процес сприйняття, який в узагальненому вигляді являє собою відбір, організацію та інтерпретацію чуттєвих даних. Ця вихідна та обов'язкова складова частина комунікації отримала назву перцептивної сторони спілкування. При цьому термін «перцептивний» тут використовується не просто як сприйняття, а як пізнавальне сприйняття співрозмовника або партнера. Сприйняття свого партнера по комунікації відбувається у вигляді його «прочитання», в ході якого розшифровуються особливості особистості, внутрішній світ та по ряду зовнішніх (в основному невербальних та паравербальних) проявів. При цьому одночасно відбувається і емоційна оцінка іншої 
людини, робиться спроба зрозуміти логіку його вчинків і мислення, а на основі цих знань будувати стратегію своєї поведінки. 3 інформаційно-психологічної точки зору розуміння є процес та механізм ідентифікації, ототожнення насамперед мовної / семіотичної форми, тобто впізнавання на перцептивному рівні, на рівні сприйняття. Таке розуміння можна умовно назвати перцептивним розумінням. Об'єктами такого розуміння можуть бути окремі слова, елементи слів, пропозиції i його частини і т.д. Поясненням для цього виступає перш за все те, що і звичайна мова, і мова художніх образів служать для вираження і передачі почуттів та думок. Саме ця обставина робить можливим семіотичний аналіз процесу розуміння як різноманітних текстів, так і творів літератури і мистецтва. Понятійне поле міжкультурного відношення в достатній мірі умовно. За допомогою комунікації особистості не тільки адаптуються до умов нової культури, а й відтворюють власні смислові границі, формують нову культурну реальність 3 мережі власних елементів та елементів іншої культури. Відносини, що складаються між культурами, в усі часи відрізнялися заплутаністю i різноманіттям; останнє, втім, не зупиняло спроби наукової думки створити класифікацією типів міжкультурної взаємодії. Безсумнівно, що найбільш значних успіхів у цьому досягла культурна антропологія, грунтуючись на великих емпіричних спостереженнях за процесами взаємодії примітивних та високорозвинених культур. Саме в рамках північноамериканської культури антропологічної традиції була вироблена методологічна основа досліджень міжкультурних відносин, яка визначається поняттям «акультурація», під якою розуміється процес прямої та досить тривалої взаємодії однієї соціальної групи з іншого.

Переконання в тому, що люди бачать світ по-різному - крізь призму своєї рідної мови, лежить в основі теорії «лінгвістичної відносністі» Е. Сепіра та Б. Уорфа. Вони прагнули довести, що відмінності між «середньоєвропейською» (західною) культурою та іншими культурними світами (зокрема культурою північноамериканських індіанців) обумовлені відмінностями в мовах. Наприклад, в європейських мовах невелику кількість речовини не можна назвати одним словом - потрібна двочленна конструкція, де одне слово вказує на кількість (форму, вмістилище), а друге - на саму речовину (зміст): стакан води, відро води, калюжа води. Б. Уорф вважає, що в даному випадку сама мова мовця 
змушує розрізняти форму і зміст, таким чином нав'язуючи їм особливе бачення світу. За Б. Уорфу, це зумовило таку характерну для західної культури категорію, як протиставлення форми і змісту. На відміну від «середньоєвропейського стандарту», в мові індіанців хопі назви речовини $є$ в той же час і назвами судин, вмістилищ різних форм, в яких ці речовини перебувають. Таким чином, двочленної конструкції європейських мов тут відповідає однослівне позначення. 3 цим пов'язана неактуальність протиставлення «форма - зміст» в культурі хопі. Б. Уорф відзначав, що «при аналізі чужої, незвичної мови ми засвоюємо ії засобами своєї рідної мови або ж виявлямо, що задача роз'яснення чисто морфологічних труднощів настільки складна, що, здається, поглинає все інше. Однак, незважаючи на складність завдання, що складається в 3'ясуванні того непрямого впливу граматичних категорій мови на поведінку людей, про яку говорилося вище, це завдання можна здійснити при розгляді якоїсь екзотичної мови, так як, вивчаючи ії, ми волею-неволею буваємо вибиті з привичної колії. I крім того, в подальшому виявляється, що така екзотична мова є дзеркалом по відношенню до рідної мови ... » [10, с. 115].

Було б помилковим припускати, що американські вчені ставили культуру в безпосередню залежність від мови. Так, Е. Сепір писав: «Культуру можна визначити як те, що дане суспільство робить і думає. Мова ж $є$ те, як думають. Важко побачити, які особливі причинні залежності можна очікувати між відібраним інвентарем досвіду (культурою - ціннісним відбором, яке здійснювало суспільство) і тим особливим прийомом, за допомогою якого суспільство висловлює всіляко свій досвід. Дрейф культури, інакше кажучи ії історія, є складний ряд змін в інвентарі відібраного суспільством досвіду - придбань, втрат, змін в оцінках і системі відносин. Дрейф мови, власне кажучи, зовсім не пов'язаний зі зміною змісту, а тільки зі зміною формального виразу ... Якби можна було показати, що у культури, незалежно від іiі реального складу, $є$ притаманна їй вроджена форма, ряд певних контурів, ми б мали в культурі щось, що може слугувати в якості підстави порівняння 3 мовою і, мабуть, засоби зв'язку з ним. Але поки нами не виявлені і не виділені такі чисто формальні сторони культури, краще буде, якщо ми визнаємо розвиток мови та розвиток культури непорівняними, взаємно не пов'язаними процесами» [9, с. 188]. 


\section{7. Міжкультурне спілкування.}

Особливе місце в теорії спілкування займає міжкультурне спілкування. Головним, але не єдиним, засобом спілкування є мова. Мова відображає культуру свого народу, його соціальний устрій, менталітет та світогляд; мова зберігає накопичений народом соціокультурний досвід, який $є$ найважливішим і ефективним способом формування особистості, тобто $\epsilon$ інструментом культури. Таким чином, можна сказати, що мова $є$ «дзеркалом» і знаряддям культури свого народу. Ситуація зіткнення культур характерна наявністю деякого поля, представленого символами і образами, з якими неминуче співвідносять себе суб'єкти міжкультурних комунікацій. Це поле визначає розвиток, зміст, характер міжкультурних комунікацій. Феномен розуміння в контексті взаємодії культури і особистості описаний в роботах Н.Н. Богомолова, А.А. Бодалева, М.Я. Блоха, В. Гумбольта, Дж. Марголіса.

У соціології культури, в роботах авторів містяться основні положення аналізу сприйняття особистістю і соціальними групами соціокультурного світу і механізмів побудови образу цього світу, вираженого феноменами культури.

Як відзначали деякі дослідники, при аналізі різних аспектів міжкультурної комунікації можуть бути використані методи герменевтики, когнітивної психології, лінгвістики, етносемантики та етнометодології.

Перерозподіл ціннісних орієнтирів в системі сучасної освіти характеризується тим, що основний упор робиться на методологічну основу, яка передбачає діалог культур, який безпосередньо зв' язаний з поняттям міжкультурної комунікації. Основними категоріями концепції діалогу культур є: культура особистість діалог текст розуміння.

За визначенням М. Бахтіна, «діалогічні відносини - це майже універсальне явище, що пронизує всю людську мову, всі відношення та прояви людського життя ... Де починається свідомість, там ... починається діалог» [1, с. 54].

Діалог іншомовних культур передбачає, що взаємодія різних картин світу, які подаються іншомовними комунікантами, включає їх логіку, мислення, ціннісні смисли і не блокується, а стимулюється за допомогою взаєморозуміння, толерантності, позитивного ставлення. Звідси міжкультурна комунікація - МКК. Процес спілкування між представ- 
никами різних народів, тобто різних мов і культур, можна назвати міжкультурним діалогом. Основна умова такого діалогу - формування білінгвальної особистості. Міжкультурна комунікація передбачає рівноправну культурну взаємодію представників різних лінгвокультурних спільнот з урахуванням їхньої самобутності та своєрідності, що призводить до необхідності виявлення загальнолюдських цінностей на основі порівняння іншомовної та власної культур. Компоненти іншомовної культури включають в себе: інформаційну або фактичну культуру - знання та відомості, якими володіє носій даного суспільства; поведінкову культуру - особливо взаємини у суспільстві, норми, цінності і т.д.; традиційну культуру - художні цінності.

\section{8. Теоретичні та методологічні основи МК}

Теоретичні та методологічні основи міжкультурної коммунікаціi таких дослідників, як, наприклад, Т.Г. Грушевіцька, В.Д. Попков, А.П. Садохін лежать в наступних положеннях. І. Функціоналізм, його основні положення і значення: ясно, що без спілкування з собі подібними людина не може стати нормальною істотою. Жодну скільки-небудь важливу для його життя задачу людина не може вирішити самостійно без допомоги людей або будь-яких установ. Тривала ізоляція людини від інших людей і від суспільства веде до його психічної та культурної деградації. Але природа не наділила людей здатністю встановлювати емоційні контакти і розуміти один одного без допомоги знаків, звуків, листів і т.д. Тому для спілкування і взаємодії люди створили спочатку природні мови, а потім різні штучні мови, символи, знаки, коди і т.п., що дозволяють налагодити ефективну комунікацію. Всі способи, форми, системи комунікації створені самими людьми і тому є елементами культури. Саме культура забезпечує нас необхідними засобами комунікації. Значення функціоналізму для процесу міжкультурної комунікації полягає перш за все в тому, що він орієнтує на розуміння інших типів культур, дослідження незвичайного способу життя, прагнення вивчити культуру зсередини, усвідомлення інших культурних цінностей. В цьому аспекті предметом дослідження в функціоналізмі стали питання взаємозалежності членів соціокультурних груп, їх конформність до очікуванням один у одного, властиві їм знання і навички, необхідні для підтримки цілісності своєї культури. 
II. Культурний релятивізм як теоретична і методологічна основа МКК. Це означає, що в процесі контактів з представниками інших культур люди зустрічаються, роблять якісь дії і вчинки, роблять обмін поглядами і думками. При цьому зміст кожної конкретної дії їм необхідно зрозуміти, бо він не завжди лежить на поверхні. Найчастіше цей сенс і значення слід шукати в традиційних для тієї чи іншої культури уявленнях про нормальні типі поведінки та відносин. Численні приклади 3 практики міжкультурної комунікації доводять, що правильний висновок про сенс відповідного вчинку можна зробити тільки з позиції внутрішньо-культурної точки зору. Адже ніякої універсальної нормальної поведінки не існує. Правила культури, до якої ми належимо, також відносні і не мають універсальної значущості. Щоб зрозуміти поведінку представника іншої культури, треба знати, наскільки традиційна його поведінка щодо його власної культури. Культура кожного народу відносна, і тому адекватно iï оцінити можна тільки в іiї власних межах закону та границях. Даний методологічний підхід в культурної антропології отримав назву культурний релятивізм. Основні ідеї культурного релятивізму були сформульовані американським соціологом У. Самнером, який вважав, що культура будь-якого народу може бути зрозуміла тільки в рамках іiї власних цінностей і в іії власному контексті. Розвиваючи цю ідею, відомий американський культурний антрополог Р. Бенедикт дала розгорнуте трактування культурного релятивізму, припустивши, що будь-яка культура має розумітися не тільки з власних передумов, а й розглядатися у своїй цілісності. Звичаї, правила, традиції не можуть бути адекватно зрозумілі або оцінені поза рамками своєї культури.

Головна ідея культурного релятивізму полягає у визнанні рівноправ'я культурних цінностей, створених і створюваних різними народами. Згідно культурному релятивізму не існує елітарних або неповноцінних культур, все культури по-своєму неповторні, і помилково порівнювати їх один з одним. Іншими словами, культури всіх народів однаково цінні, але про цінності кожної з них можна судити лише в рамках даної культури. Тим самим культурний релятивізм означає визнання самостійності та повноцінності кожної культури, заперечення абсолютного значення американської або європейської системи оцінок, принципова відмова від етноцентризму та європоцентризму при порівнянні культур різних народів. 
Принцип культурного релятивізму відіграє важливу роль в міжкультурної комунікації, оскільки вимагає поваги і терпимості до норм, цінностей і типів поведінки чужих культур. Він передбачає практичне ставлення до культури кожного народу, формуючи прагнення зрозуміти культуру зсередини, усвідомити сенс iï функціонування на основі уявлень про ідеальне і бажане, розповсюджене в ній.

III. Метод вивчення культурних систем та міжкультурних ситуацій означає, що історія становлення міжкультурної комунікації говорить про своє первісне формування на основі інтеграції різних гуманітарних наук та їх методів. Засновниками міжкультурної комунікації були представники різних наукових галузей: лінгвістики, антропології, психології, соціології, етнології, фольклористики та т.д. В процесі їх спільної роботи теорії і методи цих областей знань змішувалися, надаючи міжкультурної комунікації інтегративний характер, який був і залишається в ній до цих пір основним.

Поступово склалися три методологічних підходи до вивчення міжкультурного спілкування: а) функціональний; б) пояснювальний і в) критичний. Ці підходи грунтуються на різних уявленнях про природу людини, людську поведінку та природу людських знань. Кожний з них вносить свій внесок в наше розуміння процесу міжкультурного спілкування.

Функціональний підхід склався в 1980-і роки минулого століття та грунтується на методах соціології і психології. Відповідно до цього підходу, культуру будь-якого народу можна описати за допомогою різних методів. Будь-які зміни в культурі також можуть бути виміряні та описані. Культура визначає поведінку і спілкування людини, тому вони також піддаються опису і можуть бути передбачені. Основна мета полягає в тому, щоб показати специфіку впливу культури на комунікацію. Порівняння культурних відмінностей взаємодіючих сторін дозволяє передбачити успіх або провал їх комунікації.

Результатом функціонального підходу стала теорія комунікаційного пристосування, яка стверджує, що в ситуаціях міжкультурної комунікації люди часто змінюють моделі своєї комунікативної поведінки, пристосовуючись до моделей партнерів по спілкуванню. При цьому зміна стилю комунікації відбувається швидше під час спокійного спілкування. Навіть з власного досвіду спілкування з представниками інших культур можна зробити висновок, що краще підлаштуватися до 
співрозмовника, якщо оцінюємо його позитивно. Наприклад, при розмові з іноземцем можна говорити повільніше, чіткіше і чіткіше, полегшуючи процес спілкування для співрозмовника.

Функціональний підхід дозволяє вивчати стилі спілкування в різних культурах. Так, відомий американський дослідник міжкультурної комунікації Д. Бернланд за допомогою цього підходу порівняв стилі спілкування в Японії та США. Він встановив досить багато відмінностей, включаючи і відмінності в тому, як представники японської та американської культур говорять компліменти та вибачаються. Виявилося, що в обох культурах люди надають перевагу простим вибаченням, але американці схильні значно частіше просити вибачення та хвалити свого партнера. При виникненні одних і тих же проблем японці вважають за краще швидкі дії по їх усуненню, в той час як американці схильні давати пояснення та приносити вибачення.

Основним методом критичного підходу є аналіз текстів. По-цьому вчені зазвичай аналізують тексти, представлені в засобах масової інформації (телевізійні передачі, відеоматеріали, публікації у пресі), які, на їхню думку, вносять основний вклад у формування сучасної культури.

IV. Прикладні методи. До їх числа відносяться: біографічна рефлексія, інтерактивне моделювання, рольові ігри, самооцінка, симуляції. Як найбільш ефективні відзначимо наступні:

а) метод біографічної рефлексії передбачає осмислення власної біографії з метою з'ясування своєї власної ідентичності та форм ії прояву в повсякденному житті;

б) метод інтерактивного моделювання орієнтований на свідоме відтворення регулярно виникаючих різних індивідуальних та групових ситуацій міжкультурного спілкування. Завдяки цьому інтелектуальна та емоційна енергія учасників процесу навчання направлясться на аналіз і оцінку цих ситуацій;

в) метод рольових ігор характеризується виконанням учасниками ролей, які відтворюють часто повторювані ситуації міжкультурного спілкування;

г) метод самооцінки ставить собі за мету виділення певних типів поведінки при міжкультурному спілкуванні та розгляд їх під відповідним кутом зору. Ця мета досягається за допомогою громадських 
опитувань, структурованих спостережень і тестів; д) метод симуляції полягає в штучному створенні конкретних ситуацій міжкультурного спілкування та прогнозуванні можливих варіантів та результатів виходячи з різних точок зору і аспектів.

Практика використання розглянутих методів дозволяє прийти до висновку про те, що з їх допомогою можуть порівнюватися дві або більше культури, акцентується увага, як на загальних труднощах процесу комунікації, так і на приватних випадках міжкультурного спілкування. Використання зазначених методів в процесі навчання міжкультурної комунікації дозволяє підготувати представників різних культур до ефективних контактів з чужими культурами, навчити їх розуміти своїх партнерів по комунікації і домагатися поставлених цілей та результатів.

\section{9. Висновки}

В даний час існують різні підходи до опису міжкультурної та внутрішньо-культурної взаємодії людей в суспільстві, але дослідженню лінгвістичних та семіотичних моделей комунікації не приділяється належної уваги ні у вітчизняному, ні в зарубіжному мовознавстві.

Описані західні моделі комунікації не задовольняють сучасним вимогам. Знайомство $з$ роботами західних вчених дозволяє стверджувати: використовувані методи і підходи не охоплюють і не описують всі аспекти міжкультурної комунікації. МКК може бути досліджена або на рівні груп, або на індивідуальному рівні. Більшість досліджень, що проводилися на рівні груп, носили антропологічний і соціологічний характер. В їх основі лежали два методологічних підходи: 1) «розуміння культур як когнітивних систем», якого дотримується В. Гуденаф; 2) розуміння культури як «символічної системи» - протилежний підхід К. Гірца.

Стан сучасного суспільства, в якому однією з головних проблем $\epsilon$ проблема міжкультурної взаємодії, зумовив інтерес до досліджень культурних антропологів, зробили нове розуміння основ існування культури.

Історично склалося так, що сучасна комунікативна лінгвістика, продовжуючи традиції Ф. Шлейермахера та його «загальної» герменевтики, що вивчала процес розуміння і його закономірностей, зосередила свою увагу на умовах протікання лише успішної комунікації. 
В основі будь-якого процесу розуміння лежить саме принцип взаємодії частин і цілого, що є передумовою для застосування системного методу в кожній конкретній галузі дослідження. Таким шляхом відбувається розуміння як поведінки людей, так і продуктів їх культурно історичної діяльності.

\section{Список літератури:}

1. Бахтин М.М. Вопросы литературы и эстетики. Москва : Худ. лит., 1975.504 с.

2. Верещагин Е.М., Костомаров В.Г. Язык и культура. Москва : Индрик, 2005. $1040 \mathrm{c}$.

3. Гаспаров М.Л. Художественный мир писателя: тезаурус формальный и тезаурус функциональный. Проблемы структурной лингвистики. Москва : Наука, 1988. С. 57-71.

4. Гумбольдт В. Язык и философия культуры. Москва : Прогресс, 1985. 452 с.

5. Ильин И. Сущность и своеобразие культуры. Москва : Русская кн., 2007. 462 с.

6. Лотман Ю.М. Культура как коллективный интеллект и проблемы искусственного разума. Москва, 1977. 18 с.

7. Лотман Ю.М. Несколько мыслей о типологии культур. Языки культуры и проблемы переводимости. Москва, 1987. $256 \mathrm{c.}$

8. Рамишвили Г.В. Некоторые вопросы лингвистической теории В. Гумбольдта : автореферат дис. на соискание ученой степени кандидата филологических наук. Тбилиси, 1960. 17 с.

9. Сепир Э. Избранные труды по языкознанию и культурологии. Пер. с англ. под ред. и с предисл. А.Е. Кибрика. Москва : Прогресс: Изд. группа «Универс», 1993. 654 с.

10. Уорф Б. Отношение норм поведения и мышления к языку. Зарубежная лингвистика. № I. Москва, 1999. С. 58-92.

11. Шлейермахер Ф. Речи о религии к образованным людям, ее презирающим. Монологи. Санкт-Петербург : АО «АЛЕТЕЙЯ», 1994. 391 с.

12. Якобсон Р. Лингвистика и поэтика. Структурализм: «за и против». Москва : Издательство: Прогресс, 1975. 469 с.

\section{References:}

1. Bakhtin M.M. (1975). Voprosy literatury i estetiki [Questions of Literature and Aesthetics]. Moskva: Khud. lit. (in Russian)

2. Vereshchagin Ye.M., Kostomarov V.G. (2005). Yazyk i kul'tura [Language and Culture]. Moskva: Indrik. (in Russian)

3. Gasparov M.L. (1988). Khudozhestvennyy mir pisatelya: tezaurus formal'nyy i tezaurus funktsional'nyy [The literary world of the writer: a formal thesaurus and a functional thesaurus]. Problemy strukturnoy lingvistiki [Problems of structural linguistics]. Moskva: Nauka. (in Russian)

4. Gumbol'dt V. (1985). Yazyk i filosofiya kul'tury [Language and philosophy of culture]. Moskva: Progress. (in Russian) 
5. Il'in I. (2007). Sushchnost' i svoyeobraziye kul'tury [The essence and originality of culture]. Moskva: Russkaya kn. (in Russian)

6. Lotman Yu.M. (1977). Kul'tura kak kollektivnyy intellekt i problemy iskusstvennogo razuma [Culture as Collective Intelligence and Problems of Artificial Intelligence]. Moskva. (in Russian)

7. Lotman Yu. (1987). Neskol'ko mysley o tipologii kul'tur. Yazyki kul'tury $i$ problemy perevodimosti [Cultural languages and problems of translatability]. Moskva. (in Russian)

8. Ramishvili G.V. (1960). Nekotoryye voprosy lingvisticheskoy teorii V. Gumbol'dta: avtoreferat dis. na soiskaniye uchenoy stepeni kandidata filologicheskikh nauk [Some questions of W. Humboldt's linguistic theory: abstract dis. ... for the degree of candidate of philological sciences]. Tbilisi. (in Russian)

9. Sepir E. (1993). Izbrannyye trudy po yazykoznaniyu i kul'turologii. Per. s angl. pod red. i s predisl. A.Ye. Kibrika [Selected works on linguistics and cultural studies. transl. from English, ed. by and with a foreword of A.E. Kibrik]. Moskva: Progress: Izd. gruppa «Univers». (in Russian)

10. Uorf B. (1999). Otnosheniye norm povedeniya i myshleniya k yazyku [The relation of norms of behavior and thinking to language]. Zarubezhnaya lingvistika [Foreign linguistics], № I. Moskva, pp. 5-92. (in Russian)

11. Shleyyermakher F. (1994). Rechi o religii k obrazovannym lyudyam, yeye prezirayushchim. Monologi [Speeches about religion to educated people who despise it. Monologues]. Sankt-Peterburg: AO «ALETEYYA». (in Russian)

12. Yakobson R. (1975). Lingvistika i poetika [Linguistics and poetics]. Strukturalizm: «za i protiv» [Structuralism: pros and cons]. Moskva: Izdatel'stvo: Progress. (in Russian) 